\title{
ONTOLOGICAL STRUCTURES IN AN EDITORIAL AS A MECHANISM FOR THE CREATION OF MEANING IN PERSUASIVE PRESS TEXTS
}

\begin{abstract}
The aim of this paper is to characterise the manner in which ontological structures are created (at the level of text structure and the information layer thereof) in press discourse on the example of French newspaper editorials describing political, socio-economic conflicts between the public and the government. Ontological structures and their conceptualisation refer to one of the stages of development of global meaning in the discourse by journalists selecting and categorising the information they wish to provide to their addressees (gatekeeping). Therefore, according to the methodology proposed by Miczka (2002, 2007, 2009, 2011), connecting psycholinguistics (van Dijk \& Kintsch, 1983) with the socio-cognitive perspective (Goffman 1974/1986; Langacker, 1987), this paper will attempt to describe the discursive mechanisms of creating a common horizon for interpretation in view of persuasive function of the media language (the media declaratives) (Nowak \& Tokarski 2007, p. 12). The paper proceeds with analysis of editorials on the basis of the concept of Goffman's framework teamed with Langacker's cognitive event, as cognitive schemata organise the structure of the experimental frame. It should also be noted that the persuasiveness in the information layer of the utterance forces to ask the question of the responsibility of the media addresser towards the addressee.
\end{abstract}

Keywords: ontological structures, editorial, gatekeeping, Goffman's frame, Langacker's cognitive event.

\section{Introduction}

The purpose of this paper is to characterise the manner in which ontological structures are created (at the level of text structure and the information layer thereof) in press discourse on the example of forty French newspaper editorials (from years 2007-2008) taken from the websites of French magazines such as "Le Point", "Le Figaro", "Les Echos", "Journal l'Humanité", "Le Nouvel Observateur", "Libération" and describing the socio-economic conflicts. These conflicts concern two types of reforms, 


\section{Dominika Topa-Bryniarska}

i.e. the pension reform and the higher education reform, as proposed by the government under the presidency of Nicolas Sarkozy, which triggered a wave of protests and strikes among the affected social groups.

Ontological (semantic) structures and their conceptualisation, closely linked - in the case of media discourse - to the persuasive function of language, refer to one of the stages of development of global meaning in the discourse, consisting in a journalist's selection and categorisation of the information to be provided to an addressee. In other words, ontological structures thus include, as defined by Roche (2005, p. 56), a number of elements of reality and their mutual relationships, such as partonomy or taxonomy and distribution of semantic roles of patient and agent that in turn the addresser considers important for the implementation of their persuasive goal to convince the addressee of the addresser's own rights.

Therefore, according to the methodology proposed by Miczka (2002, 2007, 2009, 2011), connecting elements of psycholinguistics (van Dijk \& Kintsch, 1983; Coirier, Gaonac'h, \& Passerault, 1996) with the sociocognitive perspective (Goffman 1974/1986; Langacker 1987; Tabakowska, 2001; Delbecque, 2006), the paper will try to describe the discursive mechanisms of creating a common horizon for interpretation in view of persuasive function of the media language (the media declaratives) (Nowak \& Tokarski, 2007, p. 12). In the presented qualitative analysis of editorials that, in the course of further works would still need to be expanded by quantitative research on the reception of editorials by their readers, this paper will refer to Goffman's concept of framework (1974/1986), which will be teamed with the concept of Langacker's cognitive event (1987), since the cognitive schemata organise the structure of the experimental frame and provide additional information about its constituents, i.e. the agent and the patient, the used (typical) measures, tools, subjects, as well as cause and effect and time and space relationships, etc.

The thesis will graphically present configuration of the experimental frames with cognitive schemata of a cognitive event in the form of a synthetic model. It will also try to answer the question of whether the choice of a cognitive schema organising the structure of experimental frame (both phenomena are categorisation-related) may be considered a means to information filtering intended to highlight or hide some of the facts presented, so that the addressee accepted them without a shadow of a doubt as a common horizon for interpretation of the message addresser. This process bears the hallmarks of one of the techniques of manipulation, known as cognitive manipulation (Breton, 2000, pp. 101-102, French: manipulation cognitive), consisting in such a presentation of reality by means of elements known 
and accepted by the addressee, so that he would accept the transmitted information without hesitation as his own point of view.

At this point it should also be noted that persuasiveness in the information layer of the utterance expressed by juxtaposing, presenting or selecting actors of the discourse forces us to ask the question of the responsibility of the media addresser towards the addressee.

\section{Ontological structures in an editorial and the persuasive function}

In the methodology adopted herein (Miczka, 2002, 2007, 2009, 2011), which combines elements of psycholinguistics with socio-cognitive optics, it is believed that the understanding and interpretation of discourse is based on activating the knowledge acquired by the addressee, which is organised in the form of cognitive "tasks" to be performed in the course of interpreting the message. These tasks can be global or partial. The task of a global nature consists in setting the interpreted events in a certain category, i.e. recognising a specific experimental frame with the cognitive event schema organising it, which in turn allows the definition of the situation model, understood in psycholinguistics as "the representation of events, actions, their participants, states and processes fixed in episodic memory" (Miczka 2011, pp. 259-260, as translated by the author) (see also Coirier et al., 1996, p. 118).

The concept of frame has been derived from Goffman's microsociology of communication (1974/1986) examining the rituals of everyday life, where the sociologist emphasised the intersubjective, social dimension of giving meaning to something (p. 30). From this perspective, the frame is defined as a "point of reference" or interpretation schema for the identification and categorisation of everyday events (cognitive events as defined in the Langacker's theory) in a social context. Not without reason, therefore, Fauconnier (1982, p. 32) considered the frames one of the most important cognitive phenomena, emphasising that they lie at the basis of our perception and actions. ${ }^{1}$

At this point, attention should be drawn to the thematic homogeneity of the corpus (socio-economic reforms and the related conflict between the government and the society), which, for purposes of this thesis, is essential since the activated experimental frames and cognitive schemata organising those frames are related to perception and categorisation of everyday events, and thus the homogeneity of the issues of the analysed editorials al- 


\section{Dominika Topa-Bryniarska}

low a better capture of persuasive and manipulative mechanisms controlling reception of the message.

Goffman (1974/1986, p. 21 and next) distinguished two types of frameworks: the primary frameworks, activated during the perception of a phenomenon, not referring to any previous interpretations, giving the meaning to the interpreted event (and, therefore, those frames should always be activated to be able to put the situation of daily life in a particular category) and the secondary frameworks (transformed frameworks) formed on the basis of the primary frameworks due to two transformation operations, i.e. keying and fabrication.

Keying involves the use of a certain mode (a set of conventions), which, referred to the activities already meaningful, thanks to some primary framework, converts it to a qualitatively different activity (Goffman, 1974/1986, pp. 43-44). Of the five modes allowing creation of the keyed frames, Goffman (1974/1986, p. 48 and next) lists make-believe (imitation), contests (combatlike contests, sports competition), ceremonials (social ceremonies and rituals), technical redoings (repetition for technical or education purposes), regroundings (reformulation of frames) (and so it could be said that the event of a bank robbery, categorised by the primary frameworks, might be subjected to keying as a film script, which in turn could be further "keyed" in the case of film adaptation to a play).

Keying - in contrast to fabrication - is not intended to deceive another person. Fabrication, however, consists in deliberate misleading of a person or a group of persons in order to falsify their beliefs about the actual state of affairs (Goffman, 1974/1986, p. 83). Fabrications may be benign (harmless for the persons involved), for example jokes, playful fabrications, vital tests, experimental hoaxing, strategic fabrications (e.g. if we do not want to tell the whole truth to a seriously ill person), or may be exploitative (harmful to others), such as for camouflage, creation of false evidence, avowing discreditable facts, etc. (Goffman, 1974/1986, p. 87 and next).

Under the category of primary frameworks, creating a system of beliefs of a community (its cosmology), Goffman (1974/1986, pp. 22-24) also distinguishes natural frameworks and social frameworks. The former allow categorisation of geophysical phenomena independent of the human will, such as natural disasters or other natural phenomena, while the other identify phenomena dependent on human will and thoughts, i.e. piloted by human, such as sale, robbery, discussion, etc.

It seems interesting, in view of this analysis, that in the course of inter-

pretation of discourse, as in the case of the perception of everyday events, one would refer to a number of different frameworks (Goffman, 1974/1986, 
p. 25) necessary for understanding and categorisation of the phenomena described. The frameworks reconstructed by the interpreter can be combined, as indicated by Miczka (2002, p. 133), with different semantic relationships such as temporal relationship, cause and effect relationship, inclusion, opposition or exclusion.

Given the subject matter collected in the corpus, i.e. the conflict of socio-economic interests between the French society and the government, it can be expected that in the course of understanding and interpretation of such type of discourse, (at least) two conceptualisation operations take place, which is also a characteristic of press comments in general. This is a "clash" of two contrasting points of view - the thesis of a journalist and the antithesis of his/her opponent.

That bipolarisation in presentation of opinions entails a necessity to refer to at least two frameworks. As a result, a more general conclusion may be drawn that configuration and overlapping of experimental frames may, through semantic relations, constitute a basic tool for the construction of ontological structures in editorials, which is closely related to the primary function of that press genre, i.e. the function of persuasive impact on the addresse, in which a journalist or editors express their opinion on important and contemporary political and social issues (Martin-Lagardette, 1994, p. 82; Wojtak, 2010, p. 96). The many definitions of the editorial, proposed by both the Polish and French researchers, repeatedly include definitions of an editorial understood as an evaluating and interpreting genre (Herman \& Jufer, 2000) or as an analytical and directive discourse (Pisarek, 2002, p. 246; Wojtak, 2010, p. 100), where "we relate by commenting and comment by relating" (Charaudeau, 2005, p. 144, as translated by the author).

It should also be noted that at the level of information, the addresser (and not only in an editorial) occupies a privileged position with respect to the addressee, which results in a straight line from the fact that the purpose of the editorial is to transmit interpreted information, i.e. information subordinated to the act of persuasion that may also become an act of manipulation, i.e. control of message reception and instrumental treatment of the addressee by blocking his freedom of interpretation (see Breton, 2008, p. 33). That manipulation, by Breton (2000, pp. 101-102) called cognitive, manifests itself in the fact that journalists present their point of view or the results of their investigations and interpretation of facts as an objective state of affairs, somehow forcing the addressee to recognise those truths as universally applicable to the disadvantage of drawing their own conclusions. In other words, the journalist defines the concepts, ideas and phenomena 


\section{Dominika Topa-Bryniarska}

in such a manner to - in accordance with the chosen goal of communication - achieve their desired interpretation of the facts, thereby excluding other possible interpretations. Therefore, the dominant feature of the editorial is always its persuasive function (Grzmil-Tylutki, 2007, p. 210), having influence on development of the ontological domain in an editorial, which is closely related to the phenomenon of gatekeeping ${ }^{2}$ (Pisarek, 2006, p. 65; White, 1950), derived from the cognitive concept of framing adapted by the communication theory, sociology and linguistics and coined by cognitive psychologists ${ }^{3}$ (Gleason \& Ratner, 2005).

In sociology and communications studies framing is a process of selective control of the contents of media message manifesting in information filtering (gatekeeping) during which the addresser is considering putting previously selected facts in carefully selected hierarchies, categories and values (see Goffman, 1974/1986; Breton, 2000, p. 102; König, 2004).

In terms of cognitive linguistics, framing f $^{4}$ is understood as overlapping of frames, i.e. selective or fragmentary use to induce specific ideas in the mind of the addressee relating to the presented problem or issue.

Persuasion in the context of mass communication is therefore a specific variant of persuading and influencing the addressee, and the logical consequence of that persuasion (if it is successful) will be an affective and cognitive change in the message addressee (see Tokarz, 2006, pp. 194-195; Grzmil-Tylutki, 2010, p. 295; Breton, 2008, pp. 9-10). The addresser, in line with their persuasive intent, can recall various frameworks, causing a variety of reactions in the addressee, depending on the chosen social conceptualisation. This way the frames, especially those frequently appearing in the media discourse and therefore somewhat fixed, contribute to the formation of a certain affective and cognitive schemata that, in line with the established communication strategy of the addresser, are to become the frames of the addressee (Entman, 1991, p. 7), because the latter is encouraged - as noted by Kopytowska (2010, p. 261) - to adopt a horizon for interpretation shared with the addresser.

Due to the issue of subjectivity in language and denying the opposition between the fact and the comment (Rabatel, 2011, para. 28), recently widely discussed in French linguistics, one can assume that - in relation to the previously mentioned phenomenon of gatekeeping - describing events by journalists is a structure (Wolny-Zmorzyński, Kaliszewski, \& Furman, 2006, p. 140), i.e. the act of selecting the significant elements of the frame and putting aside its other elements that are considered less important (Entman, 1993, p. 53). In other words, the journalist is to decide on selection, segmentation, composition, establishing of semantic roles, highlighting or 
omitting some features of reality, ${ }^{5}$ while a particular abuse of this decision is creation of the so-called factoids (Grzmil-Tylutki, 2010, p. 227-228).

That privileged position of the addresser forces us to ask about the issue of responsibility for the utterance. This issue seems to be of importance, since it is rarely discussed in contemporary linguistic studies and discourse analysis (see Koren, 2006, p. 94). Mindful of the active presence of the journalist in the process of highlighting and presentation of information, one can cite, for example, Moirand's (2006, p. 53) attempt to define responsibilities in the press discourse that the linguists is trying to deal with in terms of ethics, relating to a manner of selecting actants, their actions, and even treating the addressee placed in the interpretation of the message, which essentially relates to the ethical level of language, e.g. through the use of marked words when naming or characterising the reality. The case is getting more complicated, however, because the issue of responsibility, especially in press discourse, covers many diverse criteria and areas. The media are an essential component of democratic governance, with the result of their specific responsibilities, but also... the difficulties in assessing the sincerity of journalists involved in various networks and relationships, such as dependence on sponsors, "environmental conspiracy" and lobbying, compliance with the ideology of the editorial board and, finally, the implicit argumentative nature of language itself (see Koren, 2006). Therefore, only the critical comparison of the various journalistic discourses (both informative and opinion-forming) allow for (objective by definition) interpretation and progressive portraying of reality (see WolnyZmorzyński et al., 2006).

\section{An example of ontological structures analysis}

Now it is time to focus on the practical aspects of the thesis. The articles collected in the corpus were analysed as follows: each editorial was search for elements of the frameworks and the event schema organising that frameworks. These elements were then grouped into relevant subcategories corresponding to constituents of frames and schemata to, based on them, outline a synthetic model for configuration of frameworks and cognitive schemata organising them.

Taking into account the issues of the analysed editorials, the configuration of frameworks and schemata, can be divided into two social frameworks relating to the amendments made by the French government (reforms) and responses of social groups affected by those reforms. 
Public reaction to the proposed reforms can take two different forms: a radical one (strikes) and a moderate one (negotiations, social discontent and criticism of the government's actions). This way, the first of the social frameworks, i.e. political activity, is invoked in the case of changes introduced by the government, while the other - the acts of violence - applies to social response to these changes and reactions of the government to social protests. The event schema organising these two frameworks is the action schema.

The constituting elements of the first of the social frameworks, i.e. the framework of political activity, can include the following components:

- the role of the agent: state authorities, e.g. the government, the president of the French Republic, the Head of State and the Prime Minister, Nicolas Sarkozy, the right wing, the left wing, the Minister of Education;

- subject performed by the agent, i.e. two reforms proposed by the government - the pension reform and the higher education reform;

- the role of the patient: social groups dissatisfied with the reforms: businesses and trade unions affected by the reforms; university, academia, professors and researchers, students, university system;

- time and place of the event: summer-autumn 200\%, France.

The role of the agent in the discussed frame of political activity is played by the French government, who are trying to impose two types of reforms on the society, perform a specific action, i.e. to run a socio-economic policy. This action "takes place" on the society playing the role of the patient, i.e. all the beneficiaries of the so-called special pensions ${ }^{6}$ and the academics. The patient himself, opposing the actions of the agent, becomes the agent, which is the basis for the activation of the second type of social framework, or the acts of aggression, expressing itself through more or less violent protests of the social groups affected by the reforms. The above mentioned framework of the acts of aggression can be divided into two groups of actants: the protesting social groups and the government responding to these forms of opposition, thus giving rise to two frameworks of the acts of aggression: one for the protesting public, and the other for the ruling responding to protests. The constituents of these two social frameworks are:

\section{- sources of the conflict:}

- for the protesting social groups (the first social framework of the acts of aggression) these are two types of reforms proposed by the government;

- for the French government (the second social framework of the acts of aggression ) these are strikes, protests of the affected social groups; 
Ontological structures in an editorial as a mechanism for the creation...

- the roles of the agent and the patient performed correspondingly under two frameworks of aggression - the protesting social groups and the French government;

- measures or tools of aggression:

- used by the protesting social groups: strikes and paralysis of public transportation, anti-government demonstrations and protests, criticism and threats against the ruling;

- used by the French government: tough negotiations, hasty modifications;

- time and place of the event: summer-autumn 200\%, France.

Below is a collective model for configuration of frameworks and event schemata, separated from the ontological structures found in the analysed editorials (see Figure 1).


cause and effect RELATIONSHIP

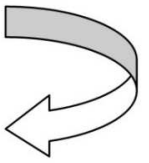

The primary social framework of the acts of aggression, based on the action schema:

- Source of conflict: two types of socio-economic reforms;

- Agent: social groups dissatisfied with the reform;

- Patient: the French government;

- Measures of aggression: paralysis of public transportation, threats and criticism of the government, demonstrations and protests;

- Time and place of the event: summer-autumn 2007, France
- Source of conflict: strikes and protests of groups affected by reforms,

- Agent: the French government;

- Patient: social groups dissatisfied with the reform;

- Measures of aggression: tough negotiations, hasty modifications;

- Time and place of the event: summer-autumn 2007, France

Figure 1. Synthetic model for configuration of frameworks and event schemata, separated from the ontological structures found in the analysed editorials

Based on the presented model, one can see that the relationship linking the two types of frameworks is the cause and effect relationship. In addition, it is worth paying more attention to the conceptualisation and distribution of semantic roles of the agent and the patient, which will be discussed below. 


\section{Dominika Topa-Bryniarska}

Since the cognitive event schema structuring the distinguished frameworks is the action schema, it is worth spending some time on its characteristics.

\subsection{The action schema and its semantic roles}

The cognitive schema of action may be reduced to the following conceptual representation: $X$ is doing $Y$, where $X$ and $Y$ refer correspondingly to the roles of an agent and a patient, and the personal form of the verb to do refers to a kind of activity performed by the agent. In relation with the arrangement of roles in the action schema, two types of questions expressing its specificity may be asked: What is $X$ doing? What is $X$ doing with Y? What is Johnny doing? Johnny is drawing. What is Johnny doing with his drawing? Johnny is destroying his drawing (see Delbecque, 2006, pp. 112-113). This model is a classic case of the action schema, where the agent (X), as indicated by Delbecque (2006, pp. 112-113) and Tabakowska (2001, p. 119), referring to the concept of Langacker (1987), is a source of energy and effort required to complete a task, while the patient (Y) is a sort of "supplementation" to this effort, in the respect that the patient is either a person or an object on which the agent's energy is focused and the addressee of that energy and effort. The agent, which is the source of strength and energy, will therefore be considered as the initiator of the action he consciously undertakes. The energy of the agent may resorb spontaneously, or may return to the agent, as in the example of Johnny is drawing or be transferred to the patient, as in Johnny is destroying his drawing.

It is worth mentioning that the addresser can always enrich the constituents of the action schema with additional information about the time, place, cause, effect, etc., taken from the activated framework this schema is organising.

In the case of social frameworks of the acts of aggression, separated during the analysis (as seen in graphical model presented earlier), it needs to be emphasised that the semantic roles of the agent and the patient are somehow becoming dual and interchangeable roles. This way, both the French government and the social groups dissatisfied with governmental reforms, alternatively play the role of the agent or the patient.

Due to the nature of the media discourse and a journalist's selective control of the content of the message, the concept of semantic role cannot be defined without taking into account the phenomenon of the gatekeeping and specific communication pact, known as factographic, occurring between the addresser and the addressee (Bauer, 2004, pp. 146-149). This 
pact imposes certain rules and regulations that must be adhered to, so that communication of media, providing a common cognitive and interpretative horizon (through appropriately activated frameworks and cognitive event schemata), could function properly. The results of the factographic pact reflected in the structure of media messages and authorise the conclusion that the media create a new type of declarativeness, the so-called media declaratives (Nowak \& Tokarski, 2007, p. 12). As explained by Nowak and Tokarski (2007), the right of the media to formulate these declaratives results mainly from the fact of using communicative scenarios, and secondly from the confrontation of opinions and views of addressees on current events with their representation in the media.

Consequently, the concept of semantic roles in the media discourse should be understood as the manner of selecting information, allowing highlighting or hiding certain selected features of reality relating to actants of the discourse. This way the distribution of semantic roles of the agent and the patient in the action schema organising two social frameworks of the acts of aggression, fits in the strategy of gatekeeping. Thanks to the interchangeability of roles assigned to the parties involved in the described socio-economic conflict, the addresser directs the message to the appropriate paths of interpretation, which enables them to model specific affective and cognitive attitudes with respect to the facts presented. Therefore, each medium can create its own vision of the world, guided by the separate selection criteria. In turn, those criteria are determined by selection of an appropriate framework - as established by the communication goal assumed by the journalist - along with the cognitive schema organising that frame, which in consequence affects the choice of roles of the agent and the patient (Delbecque, 2006, p. 109) to bring about the interpretation of the described facts desired by the addresser.

\section{Conclusions}

The presented analysis attempts to demonstrate that the act of constructing ontological structures in an editorial corresponds to persuasiveness of this type of press comment. The purpose of the thesis was to present various mechanisms of information filtering (gatekeeping) based on categorisation and prioritisation of facts which constitute the first step in the process of constructing meaning in an editorial, i.e. generating the interpreted information. The second stage of creating the meaning consists in intervening in the language layer of an utterance. 


\section{Dominika Topa-Bryniarska}

By segmenting the described phenomena, processes and ideas, as well as other relationships mutually connecting them, which is made possible by reference to the particular frameworks and cognitive schemata, the journalist fulfils the specific role of "information architect", which confirms the fact that the media not only describe, but also generate reality, creating new semantic elements. Therefore, at the level of ontological structures in the media discourse, the addresser affects the significance of the information selecting and overlapping frameworks, since he or she is able to determine the scope of more or less important issues, capture cognitive stereotypes and evaluate related phenomena (see Grzmil-Tylutki, 2010, p. 317), and thus increase the probability that the reader would remember the information, or perform an effective act of persuasion.

An essential element of the construction of ontological structures is also distribution of semantic roles. These roles may be - as in the case of the analysed editorials - interchangeable or permanently assigned to the specific actors of the discourse, depending on what the addresser wants to highlight. Assignment of semantic roles is determined in an editorial by the dominant persuasive function designed to eliminate or make a different point of view than the one adopted by the addresser less probable and which, in the case of manipulation of the message, the addresser wishes to present as the only right and objective one.

Interchangeability and bipolar distribution of semantic roles that could be seen in the examined articles allow for presentation of the same actant twofold - as a victim and an aggressor, which, in turn, promotes a specific valuation, influencing the emotional focus of the message.

Since the conceptualisation based on the interchangeability of semantic roles allows omitting or highlighting certain aspects of reality perceived by a journalist as important, another interesting research problem would be, in our view, extending the analysis of ontological structures in the editorial of its axiological structures, which follows directly from the fact that categorisations activated in the process of conceptualisation are inherently characterised by a specific valorisation, as they arise from the system or systems of values adopted by the journalist.

As a result, if the first step in creating meaning in the editorial is its ontological domain opening the message to valuation and addition of emotions, then the second necessary stage will be consolidation and preservation of that axiologisation using suitable means of persuasive language, as expressed by Plantin (2011, p. 182) in his statement that each structure of events has an inevitable emotional attitude towards what is presented, thereby activating specific affective and cognitive schemata. And while "the 
emotions confirm the speaker's credibility" (Plantin, 2011, p. 182, as translated by the author), the use of suggestive, emotional forms of expression can help returning to the question of responsibility for a word in the media discourse, which, by proper correlation of ontological structures with axiological structures is to somehow force the addressee to adopt a particular attitude, positive or negative, towards the facts presented. Thus, linguistic expressions are a sort of catalyst that enables "penetration" of the specific ontological structures and associated categorisation to the mind and consciousness of the addressee.

It should also be noted that, in modern models of mass communication, an interactive nature of communication is assumed (Hall, 1980), as opposed to earlier concepts treating the reader (spectator) as a passive and submissive recipient (Laswell, 1927). However, this does not contradict the assumption that the flow of socio-cultural values, without which communication of the media would be neither possible nor effective, is an integral component of any such communication, even if in the interactive and polysemic model, the addressee may accept or reject the meaning of the message encoded by the addresser (see Kopytowska 2010, pp. 258-259).

And though the mass media are not the only source of the activator of frameworks, there is no doubt that we are now in an era when everyone talks about the famous "Fourth Estate" and the related information society. This society is building its vision of the world based on content submitted by media broadcasters, and this is reflected in the discourse of mass communication, primarily aimed at creation of new standards and social values, or modification of the existing ones. This inevitably leads to the development of social behaviours as a result of controlling perception and awareness of the addressees (see Lazar, 1995).

Finally, it should be emphasised that hypotheses presented in this study on manipulation of ontological (semantic) structures in the discourse and perception of the filtered information by the public is the first stage of the conducted research. The presented qualitative analysis is only an attempt to capture mechanisms used for adding emotions to utterances and controlling reception of the media message. Thus, the next stage of the research will be a quantitative analysis allowing enhancing the interpretation of the results obtained and verifying to what extent the structures and resources described can be considered representative for the editorial. That analysis will be then confronted with data from ethnographic interviews and focus groups of readers in the hope that the obtained results would contribute to the enrichment of the already available knowledge on the processing of information and its linguistic representation, not only in the press commen- 


\section{Dominika Topa-Bryniarska}

tary, but also in the discourse of mass communication in general to allow us to become familiarised with the processes of manipulation, but also, and perhaps above all, to be able to defend against those processes.

\section{N O T E S}

${ }^{1}$ A slightly different perspective on the issue of the frame can be found in Fauconnier's theory of mental spaces (1984), where the concept of mental frame (French: espace mental) is defined more narrowly than Goffman's concept of frame. Mental spaces can be visualised as a kind of container used to collect, build and develop the conceptual content. According to Fauconnier (1984, p.32), mental spaces are defined as ensembles structurés, modifiables, construits dans chaque discours en accord avec les indications fournies par les expressions linguistiques, or structured whole, activated on the basis of specific linguistic expressions, and therefore formed as an ad hoc and individual image activated for a short time in order to understand the situation. The experimental frame, similarily to Langacker's cognitive domain, is a fairly static, permanent structure organising knowledge of a concept.

2 The notion of gatekeeping is derived from the term of gate keeper, first used by White (1950) with regard to a newspaper editor making decision on the selection of information worth publishing.

${ }^{3}$ In cognitive psychology framing is defined as the cognitive phenomenon being an integral part of the categorisation process, where new information is assigned to categories of previously acquired experience (see Gleason \& Ratner, 2005).

4 The notion of the frame within the meaning of broader units of knowledge referred to by words in the communication process, was introduced to linguistics by Fillmore (1985) under the concept of the semantics of understanding (or U-semantics) formed in opposition to the semantics of truth (or T-semantics).

${ }^{5}$ In the French theory of enunciation, known as effacement énonciatif, (enunciative effacement), this position of the journalist, being an expression of the dominant point of view, is defined as superenunciator (French: sur-énonciateur) (see Rabatel, 2004). The position of the superenunciator is of particular importance in the case of opinion-forming texts.

6 The scope of the French special pension scheme (French: régimes spéciaux de retraite) embraces the employees in the public sector (railways, gas, electricity, military, police) and sailors, artists, civil notaries, etc.

\section{R E F E R E N C E S}

Bauer, Z. (2004). Gatunki dziennikarskie. In Z. Bauer \& E. Chudziński (Eds.), Dziennikarstwo i świat mediów (pp. 143-173). Kraków: Universitas.

Breton, Ph. (2000). La parole manipulée. Paris: La Découverte Poche.

Breton, Ph. (2008). Convaincre sans manipuler. Apprendre à argumenter. Paris: La Découverte.

Charaudeau, P. (2005). Les médias et l'information. L'impossible transparence du discours. Bruxelles: De Boeck. 
Ontological structures in an editorial as a mechanism for the creation...

Coirier, P., Gaonac'h, D., \& Passerault, J.-M. (1996). Psycholinguistique textuelle. Une approche cognitive de la compréhension et de la production des textes. Paris: Armand Colin.

Dijk Van, T. A. \& Kintsch, W. (1983). Strategies of Discourse Comprehension. New York: Academic Press.

Delbecque, N. (Ed.). (2006). Linguistique cognitive. Comprendre comment fonctionne le langage. Préface de Jean-Rémi Lapaire. Bruxelles: Champs linguistiques De Boeck-Duculot.

Entman, R. M. (1991). Framing U.S. coverage of international news. Contrasts in narratives of KAL and Iran Air incidents. Journal of Communication, 41 (4), 6-27. DOI: 10.1111/j.1460-2466.1991.tb02328.x

Entman, R. M. (1993). Framing: Toward clarification of a fractured paradigm. Journal of Communication, 43 (4), 52-57. DOI: 10.1111/j.1460-2466.1993.tb013 04.x

Fauconnier, G. (1984). Espaces mentaux. Aspects de la construction du sens dans les langues naturelles. Paris: Minuit.

Fauconnier, G. (2004). Pragmatics and cognitive linguistics. In L. Hord \& G. Ward (Eds.), The Handbook of Pragmatics (pp. 657-674). Oxford: Blackwell Publishing.

Fillmore, Ch. (1985). Frames and the Semantic of Understanding. Quaderni di Semantica, 6, 222-253.

Gleason J. B. \& Ratner N. (2005). Psycholingwistyka. Gdańsk: Gdańskie Wydawnictwo Psychologiczne.

Goffman, E. (1986). Frame Analysis. An Essay on the Organization of Experience (reprint). Boston: Northeastern University Press. (Original work published 1974)

Grzmil-Tylutki, H. (2007). Gatunek w świetle francuskiej teorii dyskursu. Kraków: Universitas.

Grzmil-Tylutki, H. (2010). Francuska lingwistyczna teoria dyskursu. Historia, tendencje, perspektywy. Kraków: Universitas.

Hall, S. (1980). Encoding and decoding in the television message. In S. Hall, D. Hobson, A. Lowe, \& P. Willis (Eds.), Culture, Media, Language: Working Papers in Cultural Studies, 1972-1979 (pp. 128-138). London: Hutchinson.

Herman, T. \& Jufer, N. (2001). L'éditorial « vitrine idéologique» du journal? $S e$ men, 13, 135-162.

König, T. (2004). Frame Analysis: A Primer. Retrieved May, 9, 2013 from ESRC ReStore: http://www.restore.ac.uk/lboro/resources/links/frames_primer.php

Koren, R. (2006). La responsabilité des Uns dans le regard des Autres: l'effacement énonciatif au prisme de la prise de position argumentative. Semen, 22, 93108. 


\section{Dominika Topa-Bryniarska}

Kopytowska, M. (2010). Dlaczego Afryka przeraża - ramy w dyskursie wiadomości prasowych. In J. Nijakowska (Ed.), Język a komunikacja 28. Interdyscyplinarne studia nad świadomościa i przetwarzaniem (pp. 257-275). Kraków: Tertium.

Langacker, R. (1987). Foundations of cognitive grammar. Vol. 1: Theoretical Prerequisites. Stanford: Stanford University Press.

Laswell, H. D. (1927). Propaganda Technique in the World War. New York: Peter Smith.

Lazar, J. (1995). L'opinion publique. Paris: Sirey.

Martin-Lagardette, J.-L. (1994). Guide de l'écriture journalistique. Ecrire, informer, convaincre. Paris: Syros.

Miczka, E. (2002). Kognitywne struktury informacyjne w interpretacji dyskursu. Katowice: Wydawnictwo Uniwersytetu Śląskiego.

Miczka, E. (2007). L'application des notions de «cadre de l'expérience et d'« événement cognitive » à l'analyse de discours - cas du fait divers. Neophilologica, 19, 138-146.

Miczka, E. (2009). Les structures situationnelles et informationnelles de discours. Etudes cognitive, 9, 11-21.

Miczka, E. (2011). Relations entre les cadres de l'expérience dans le discours exemple du fait divers. Neophilologica, 23, 259-272.

Moirand, S. (2006). Responsabilité et énonciation dans la presse quotidienne: questionnement sur les observables et les catégories d'analyse. Semen, 22, 45-60.

Nowak, P. \& Tokarski, R. (2007). Medialna wizja świata a kreatywność język. In Kreowanie świata w języku mediów. Materiały z konferencji, 24-26 października 2005 (pp. 9-35). Lublin: Wydawnictwo Uniwersytetu Marii Curie-Skłodowskiej.

Pisarek, W. (Ed.). (2006). Stownik terminologii medialnej. Kraków: Universitas.

Plantin, Ch. (2011). Les bonnes raison des émotions. Principes et méthode pour l'étude du discours émotionné. Coll. Sciences pour la communication. Berne: Peter Lang.

Rabatel, A. (2004). L'effacement énonciatif dans les discours rapportés et ses effets pragmatiques. Langages, 156, 3-17. DOI: 10.3406/lgge.2004.960

Rabatel, A. (2011). Des conflits de valeurs et de points de vue en discours. Semen, 32, 55-72.

Roche, Ch. (2005). Terminologie et ontology. Langages, 157, 48-62. DOI: 10.3406/ lgge.2005.974

Tabakowska, E. (Ed.). (2001). Kognitywne podstawy języka i językoznawstwa. Kraków: Universitas.

Tokarz, M. (2006). Argumentacja, perswazja, manipulacja. Wyktad z teorii komunikacji. Gdańsk: Gdańskie Wydawnictwo Psychologiczne. 
Ontological structures in an editorial as a mechanism for the creation...

Warchala, J. (2004). Horyzonty manipulacji: perswazja, manipulacja, interpretacja. In P. Krzyżanowski \& P. Nowak (Eds.), Manipulacja w języku (pp. 41-59). Lublin: Wydawnictwo Uniwersytetu Marii Curie-Skłodowskiej.

White, D. M. (1950). The "gate keeper": A case study in the selection of news. Journalism Quarterly, 27, 383-391.

Wojtak, M. (2010). Analiza gatunków prasowych. Lublin: Wydawnictwo Uniwersytetu Marii Curie-Skłodowskiej.

Wolny-Zmorzyński, K., Kaliszewski, A., \& Furman, W. (2006). Gatunki dziennikarskie. Teoria, praktyka, jezyk. Warszawa: Wydawnictwa Akademickie i Profesjonalne. 